\title{
3.3 Основні пріоритети реалізації інноваційної діяльності в Україні
}

Існує кореляція між поняттям «інновація» та «конкурентоспроможність»: що вищий ступінь розвитку інновацій, то вища конкурентоспроможність економіки, тобто система здатна виробляти продукцію нової якості, на яку є більший попит, із меншими витратами тощо. Україна в цьому питанні суттєво відстає від топ-групи держав i, як результат, володіє економікою з низькою доданою вартістю, неконкурентоспроможною продукцією, орієнтованою на видобуток та мінімальну обробку сировини, імпортує високотехнологічне обладнання. Частка нематеріальних активів у собівартості української продукції не перевищує 0,5-2\%, що в 20 та більше разів нижче, ніж в економічно розвинених країнах [70]. В цілому, зазначене негативно впливає на інноваційний розвиток економіки, сприяє підвищенню рівня «тінізації» економіки й зниження рівня економічної безпеки держави.

Згідно закону України «Про інноваційну діяльність» [71]:

інновації - «новостворені (застосовані) і (або) вдосконалені конкурентоздатні технології, продукція або послуги, а також організаційнотехнічні рішення виробничого, адміністративного, комерційного або іншого характеру, що істотно поліпшують структуру та якість виробництва і (або) соціальної сфери»;

Серед економістів, які досліджували проблеми нововведень, важливе місце належить німецькому вченому Г. Меншу, який здійснив спроби пов'язати темпи економічного зростання й циклічність із появою базисних нововведень. Він вважав, що в моменти, коли базисні нововведення вичерпують свій потенціал, виникає ситуація «технологічного пата», що й визначає застій в економічному розвитку [72, с. 14]. Менш стверджував, що промисловий розвиток - це перехід від одного технологічного пата до іншого. Завдяки появі базисних нововведень виникають нові підприємства, цикли розвитку яких взаємозалежні. Виробництво нових товарів на початковій стадії, як правило, відстає від попиту й тому характеризується в цей період високими темпами зростання. Менш пов'язува 
циклічність економіки 3 циклічністю нововведень та фазами розвитку нових підприємств. Він вказував на момент, коли виробництво нових товарів починає перевищувати попит. Від цього часу фірми починають шукати виходи на зовнішні ринки, падає норма прибутку, і все менше засобів спрямовується на інвестиції. Капітали перетікають на фінансові ринки. Рано чи пізно спекулятивні фінансові операції сягають гігантських розмірів, і норма прибутку в грошовокредитній сфері стає нижчою від такої у промисловості. 3 точки зору Г. Менша, це означає, що фінансова сфера дозріла для інвестицій у реальний сектор.

Багато положень концепції Г. Менша були критично розглянуто й розвинуто іншими авторами. Зокрема, німецький економіст А. Кляйнкнехт уточнює тезу про формування кластерів інновацій на стадії депресії. Він вважає, що кластери інновацій-продуктів дійсно утворяться на фазі депресії, а от інновацій-процесів - на стадії підвищення «довгої хвилі» [73].

Значне місце в теорії інноваційного менеджменту посідають концепції, що висвітлюють формування технологічних систем та способи поширення інновацій. Ці концепції розвиває ряд учених, серед яких можна виділити англійських економістів К. Фрімена, Д. Кларка та Л. Суїте. Вони ввели поняття технологічної системи взаємозалежних сімейств технічних та соціальних інновацій. Автори вважали, що темпи економічного зростання залежать від формування, розвитку та старіння технологічних систем. Дифузія, або процес поширення інновацій, розглядається ними як механізм розвитку технологічної системи. Автори пов’язували темпи дифузії нововведень 3 ринковим механізмом. Вони відзначали, що дифузія інновацій вимагає відповідних умов і стимулювання. Поштовхом до розвитку економіки слугує поява базисних інновацій в окремих секторах економіки (тут проглядається подібність 3 концепцією Менша). Старіння технологічних систем в одних країнах та поява нових в інших призводить до нерівномірності міждержавного розвитку. Економічне зростання розглядається як наслідок появи нових галузей.

Певіт та Уолкер виділяли сім типів інновацій, залежно від ступеня використання в них наукових знань та їхнього широкого використання [74]: 
1) засновані на використанні фундаментальних наукових знань, результати яких широко застосовуються у різних сферах суспільної діяльності (ЕОМ тощо);

2) інновації, що також базуються на наукових дослідженнях, проте мають обмежену сферу використання (зокрема, вимірювальні прилади для хімічного виробництва);

3) розроблені 3 використанням вже існуючих технічних знань нововведення 3 обмеженою сферою використання (зокрема, новий тип змішувача для сипучих матеріалів);

4) інновації, що входять у комбінації різних типів знань в одному продукті;

5) використання одного продукту в різних галузях;

6) технічно складні нововведення, що виникли як побічний результат великої дослідницької програми (керамічна каструля, створена на основі досліджень, що проводилися в рамках космічної програми);

7) використання вже відомої техніки або методів у новій сфері.

У загальному вигляді інноваційний процес являє собою одержання i комерціалізацію винаходу, нових технологій, видів продуктів і послуг, рішень виробничого, фінансового, адміністративного або іншого характеру й інших результатів інтелектуальної діяльності.

Зародження інноваційної ідеї і можливість використання нових наукових результатів відбуваються на етапі фундаментальних та пошукових досліджень, прикладних досліджень і розробок [75].

Позитивний досвід багатьох країн свідчить про перспективність для широкого й ефективного впровадження новітніх технологій, комерційної реалізації інновацій, створених внаслідок наукових досліджень і розробок, функціонування мережі таких інноваційних структур як технологічні (наукові) парки, технополіси, інноваційні бізнес-інкубатори, інноваційно-технологічні центри, малі й середні інноваційні підприємства тощо [76].

Основною метою створення технопарків, технополісів та інших інноваційних структур є тісне зближення наукового й освітнього потенціалу того чи іншого регіону з матеріально-технічною базою промисловості, скорочення 
тривалості інноваційного циклу, забезпечення вирівнювання науковотехнологічного та інноваційного розвитку різних регіонів, активізація малого інноваційного бізнесу. Технопарк сприяє концентрації уваги вчених на можливих комерційних застосуваннях майбутніх результатів досліджень. Водночас технопарк є лише засобом комерціалізації інновацій, що надає вченим, науково-педагогічним працівникам закладів вищої освіти можливість здійснювати співробітництво з базовою науковою організацією, де вони можуть i надалі користуватися лабораторним устаткуванням, каналами інформації, бібліотекою, спілкуватися 3 колегами, залучати до роботи на своїй фірмі колишніх студентів і аспірантів. В умовах технопарку вчений може працювати за сумісництвом, не перериваючи наукового чи навчального процесу [76].

Як свідчить зарубіжний досвід, технопарки добре вписуються у стратегію регіонального розвитку, виступають каталізатором позитивних змін у регіоні, механізму реалізації регіональної політики, спрямованої на перебудову промисловості на основі новітніх технологій [77-78].

«Науковий (технологічний) парк - науково-виробничий (як правило територіальний) комплекс, до якого входять дослідницький центр і прилегла до нього компактна виробнича база, у якій на умовах оренди розміщуються малі наукомісткі фірми».

У ролі дослідницького центру можуть виступати: заклад вищої освіти (університет), державна лабораторія або інститут, науково-дослідний підрозділ організації державного або приватного сектору. Найпоширеніший у промислово розвинених країнах варіант пов'язаний з університетами, де великі ЗВО є головними центрами фундаментальної та прикладної науки. Ефективне функціонування технопарків, бізнес-інкубаторів, інших інноваційних структур, малих та середніх інноваційних підприємств потребує створення розвиненої інноваційної, ринкової та побутової інфраструктури [76]. Серед інноваційних структур чільне місце посідають малі інноваційні підприємства, для становлення й розвитку яких значною мірою й створюється «надбудова» 3 технопарків, технополісів, бізнес-інкубаторів та інноваційно-технологічних центрів. 
Будь-який результат інноваційної діяльності у вартісному виразі узагальнюється економічним ефектом. Ефекти інноваційної діяльності взаємопов'язані між собою (рис. 1). Безпосередньо економічні результати від інноваційної діяльності пов'язані із науково-технічним, податковим і соціальним ефектами. У свою чергу, ресурсний й екологічний ефекти виникають лише як наслідок науково-технічного прогресу й опосередковано впливають на економічний ефект від інноваційної діяльності.

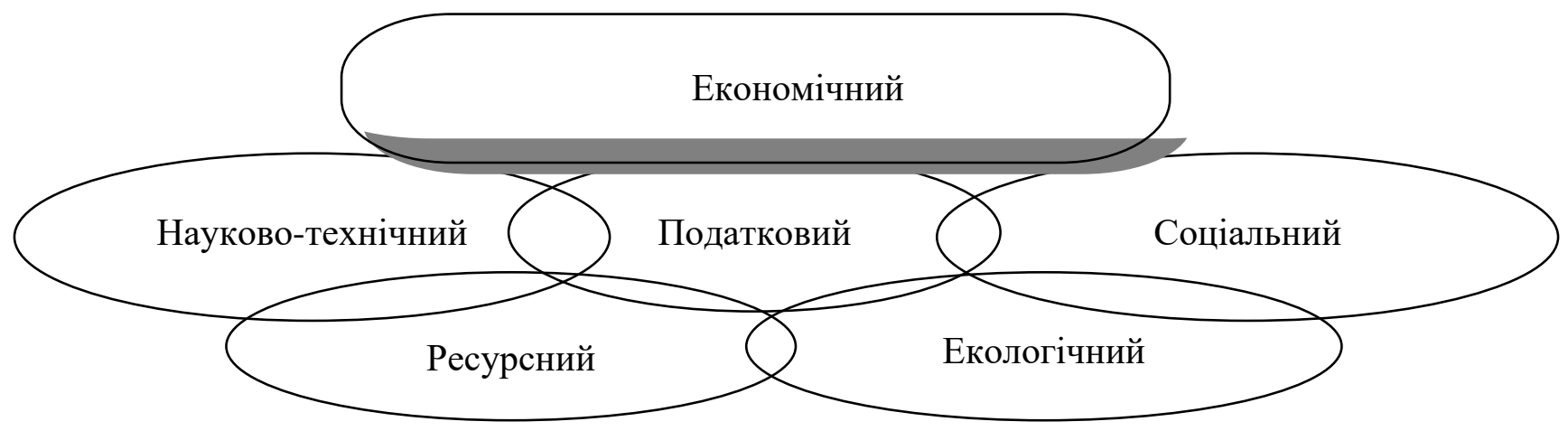

Рис. 1. Ієрархічна супідрядність та взаємозв'язок ефектів інноваційної діяльності

Джерело *. Систематизовано, узагальнено та згруповано за даними [79, с. 34].

Для об’єктивного оцінювання стану інноваційного розвитку України важливе значення має визначення іiі відносної позиції в рамках країн Європейського Союзу за допомогою Європейського інноваційного індексу, Європейського інноваційного табло. Інформативним та таким, що може бути цінним з практичної точки зору, є досвід країн ЄС. Європейський Союз володіє потужним інтелектуальним та технологічним потенціалом. У XXI ст. Європейський Союз стає одним із ініціаторів інноваційних стратегій сталого розвитку, інноваційний розвиток співтовариства стає головним стратегічним напрямом глобальної інтеграційної стратегії $\mathrm{CC}$, економіка знань та інновації офіційно проголошені стратегічними пріоритетами $\mathrm{CC}$ протягом останніх двох десятиліть, зростає роль інноваційної політики. Інноваційна політика таким чином має стати одночасно і дієвим інструментом післякризового відновлення економіки, і механізмом, що забезпечить нарощування потенціалу промислового виробництва як основи економічного зростання СС у XXI ст. [80]. 
Системний характер інноваційної політики $С \mathrm{C}$ передбачає впровадження інновацій в усі сфери життя. Важливою складовою інноваційної моделі розвитку ЄС виступає інноваційне підприємництво як особливий вид комерційної діяльності, що має за мету отримання прибутку за допомогою активного поширення інновацій в усіх секторах економіки. Вивчення та узагальнення досвіду ЄС щодо побудови інноваційної моделі розвитку, інноваційного підприємництва має створити грунтовний фундамент системних перетворень на основі оновленої стратегії інноваційного конкурентоспроможного розвитку України й надасть можливість брати участь у нових програмах Євросоюзу [70].

Загалом можна виділити такі проблемами розвитку інноваційної діяльності:

- недостатній обсяг заощаджень населення, коштів суб'єктів господарювання та держави для здійснення інвестицій 3 метою реалізації інвестиційних та інноваційних проєктів;

- невизначеність правового інструменту залучення недержавних інвестицій з метою розвитку економіки, у тому числі механізму

- низький забезпечення розвитку державно-приватного партнерства;

- низькі темпи впровадження високих технологій;

- висока енергоємність внутрішнього валового продукту;

- зношеність основних засоби;

- недосконалість законодавства щодо розвитку інноваційної діяльності;

- невиконання суб'єктами господарювання вимог законодавства щодо взяття на облік об'єктів права інтелектуальної власності та відсутність механізму заохочення введення таких об'єктів у комерційний обіг;

- нерозвиненість інноваційної інфраструктури, недостатня кількість інноваційних підприємств (інноваційних центрів, технопарків, технополісів, інноваційних бізнес-інкубаторів), наукових парків, центрів трансферу технологій і промислових кластерів;

- недосконалість механізму комерціалізації результатів наукових досліджень та розробок; 
- невизначеність пріоритетів розвитку базових галузей економіки та відсутність сприятливих умов для залучення інвестицій з метою забезпечення розвитку високотехнологічного виробництва;

- незначна кількість вітчизняних виробників високотехнологічної продукції, що беруть участь у міжнародному обміні технологіями, у зв“язку 3 недосконалістю законодавства щодо трансферу технологій;

- недостатня державна підтримка впровадження інновацій для забезпечення розвитку малого і середнього підприємництва [70].

Розв'язання зазначених проблем потребує активізації інвестиційної та інноваційної діяльності, спрямованої на забезпечення розвитку базових секторів економіки. 3 урахуванням зазначеного доцільним вбачається здійснювати розроблення та впровадження адекватних сучасним умовам заходів, які за своєю сутністю є пріоритетами реалізації інноваційної діяльності в Україні. До основних з таких заходів слід віднести такі:

- створення сприятливих базових макроумов, які є фундаментом для будьякого економічного розвитку (верховенство права, викорінення корупції, посилення енергоефективності);

- покращення якості технічної освіти, популяризації науки й техніки;

- покращення державної інноваційної інфраструктури за рахунок широкого впровадження механізмів приватної та державної співпраці;

- створення нових моделей організації взаємодії на лінії наука / знання виробництво, зокрема за рахунок створення інноваційної інфраструктури, спроможної максимально швидко впроваджувати знання в економіку;

- створення інформаційних платформ-зв'язків між наукою й бізнесом задля переходу на модель «відкритих інновацій» за рахунок широкого нетворкінгу, інтенсивного обміну інформацією та доступу до міжнародних ринків, мультинаціональних корпорацій та інновацій міжнародних кластерів;

- широке впровадження IT рішень в усі сфери економіки [70].

Зважаючи на вищенаведене, слід зазначити, що реалізація запропонованих заходів сприятиме підвищенню рівня інноваційного розвитку економіки, 
забезпеченню висхідного тренду економічного зростання, зниженню рівня «тінізації» економіки й підвищенню економічної безпеки держави загалом [8185] й можлива за умови урахування українських реалій та підтримки на всіх рівнях управління. 